Canadian

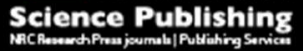

Botany

Botanique

\title{
Spatial and temporal assessments of genetic structure in an endangered Garry oak ecosystem on Vancouver Island
}

\begin{tabular}{|c|c|}
\hline Journal: & Botany \\
\hline Manuscript ID & cjb-2017-0130.R2 \\
\hline Manuscript Type: & Article \\
\hline Date Submitted by the Author: & $15-J a n-2018$ \\
\hline Complete List of Authors: & $\begin{array}{l}\text { Catherall, Erin; Vancouver Island University, Biology Department } \\
\text { Janes, Jasmine; Vancouver Island University, Biology Department; } \\
\text { University of New England, School of Environmental and Rural Science } \\
\text { Josefsson, Caroline; Vancouver Island University, Biology Department } \\
\text { Gorrell, Jamieson; Vancouver Island University, Biology Department }\end{array}$ \\
\hline $\begin{array}{r}\text { Is the invited manuscript for } \\
\text { consideration in a Special } \\
\text { Issue? : }\end{array}$ & N/A \\
\hline Keyword: & $\begin{array}{l}\text { diameter at breast height, Garry oak, genetic structure, microsatellites, } \\
<i>\text { Quercus garryana }</ i>\end{array}$ \\
\hline
\end{tabular}




\section{Spatial and temporal assessments of genetic structure in an endangered Garry oak ecosystem on Vancouver Island}

Erin E. Catherall ${ }^{1}$, Jasmine K. Janes ${ }^{1,2}$, Caroline A. Josefsson ${ }^{1}$, Jamieson C. Gorrell ${ }^{1,{ }^{*}}$

1. Biology Department, Vancouver Island University, 900 Fifth St., Nanaimo, British Columbia, Canada, V9R 5S5

2. School of Environmental and Rural Science, The University of New England, Armidale, NSW, Australia, 2351

Erin Catherall erincatherall@gmail.com

Jasmine Janes jjanes@une.edu.au

Caroline Josefsson Caroline.Josefsson@,viu.ca

*Corresponding author: jamie.gorrell@,viu.ca (250) 753-3245 ext. 2314 


\begin{abstract}
Garry oak (Quercus garryana Dougl. ex Hook.) is a deciduous tree whose ecosystem is listed "at-risk" throughout its range in British Columbia (B.C.), Canada, under the Canadian Species at Risk Act (SARA). Garry oak ecosystems host the most diverse flora for coastal B.C. yet they account for less than $0.3 \%$ of the province's landbase. Due to the loss and degradation of Garry oak habitat, many associated plant and animal species that rely on these sensitive ecosystems are endangered. Microsatellite markers were used to investigate temporal changes in fine-scale population genetic structure of 121 Garry oak trees from the Nanaimo region (Vancouver Island, B.C.) using diameter at breast height as a proxy for age. Overall, allelic diversity was moderate, ranging from 3.0 to 7.5 alleles per locus with an average of $4.4( \pm 0.4 \mathrm{SE})$ across all loci. Global $F_{S T}$ of 0.06 and 0.09 suggests significant departures from Hardy-Weinberg equilibrium among all populations and age-classified subpopulations, respectively. We found no evidence for change in genetic diversity across generations. Our results indicate low levels of differentiation within populations and high levels of gene flow among populations, suggesting an adaptive potential for Garry oaks in response to future climate change events.
\end{abstract}

Keywords: diameter at breast height, Garry oak, genetic structure, microsatellites, Quercus garryana 


\section{INTRODUCTION}

Garry oak (Fagaceae: Quercus garryana Dougl. ex Hook.) is the only native oak species found in British Columbia (B.C.), Canada. The current distribution of Garry oak ranges from the Pacific Coast of south-central California to the driest regions in southcoastal B.C. The northern-most range of Garry oak is restricted to the Coastal Douglas-fir (Pseudotsuga menziesii) biogeoclimatic zone of Vancouver Island and adjacent Gulf Islands and two distinct mainland B.C. populations in the Fraser Valley and Fraser Canyon. These areas are characterized by a submediterranean climate and moderately infertile, acidic soils of postglacial origin (MacDougall et al. 2004).

Paleoecological records from Vancouver Island suggest that Garry oaks arrived in B.C. 8,000 years ago (Pellatt et al. 2001; Brown and Hebda 2002). Pollen records suggest that the maximum westward extension of Garry oak ecosystems (GOE) on Vancouver Island occurred 6,000 years ago during the mid-Holocene period (Pellatt et al. 2001; Brown and Hebda 2002) but contracted to areas with more distinct submediterranean climates around 4,000 years ago when the climate became cooler. These early GOE appear to have been preserved by the fire management practices of First Nations people (Erickson 1996; MacDougall 2004), which promoted a heterogeneous forest composition by preventing succession to Douglas-fir forests (Burke et al. 2015).

By the late 19th century, European settlement had contributed to significant habitat loss and high levels of exotic plant invasion in GOE through extensive agricultural grazing, cultivation, and the introduction of Eurasian pasture flora (Fuchs 2001; MacDougall et al. 2004). In addition, European settlers disrupted the fire regimes implemented by First Nations (McCoy 2006) consequently impacting the preservation of GOE and the maintenance of heterogeneous forest compositions. 
Today, GOE account for less than $0.3 \%$ of B.C.'s land coverage where they support the largest concentration of rare species in the province (Ward et al. 1998; Huebert 2009). These northern-most GOE are of great conservation concern as succession to coniferous forest, urban encroachment, and changes in disturbance regime (i.e. fire suppression) (Dunwiddie et al. 2011) continue to impact distribution and composition. Thus, many associated plant and animal species that rely on GOE are listed at risk of extirpation from Canada (Darling 2000). As a result, many ongoing management efforts aim to preserve and restore the remaining GOE within B.C. While current Garry oak populations are declining, climatic envelope models suggest that species' realized niche space will likely move northward with the progression of climate change (Davis and Shaw 2001; Pellatt et al. 2012). However, this northward migration is expected to stop around the Georgia Depression due to Insular and Coastal mountain ranges of coastal B.C. (Pellatt et al. 2012; Pellatt and Gedalof 2014). This spatial redistribution could replace much of what is currently Douglas-fir forest in coastal B.C.; however, the potential for Garry oak to adapt to climate change will depend on genetic variation, dispersal and establishment rates (Fuchs 2001; Savolainen et al. 2007).

Few studies have addressed the conservation and phylogeography of Garry oaks with genetic markers. Using isozyme markers, Ritland et al. (2005) found that levels of genetic diversity and inbreeding did not vary greatly among oak populations on Vancouver Island, although allelic diversity decreased northwards across mainland B.C., Washington and Oregon, U.S.A. Marsico et al. (2009) discovered strong population differentiation using chloroplast markers, but weak differentiation using nuclear markers among populations in the same geographic areas as Ritland et al. (2005). These results 
suggest that pollen, but not seed, are readily dispersed over long distances. Another study using a common garden experiment found that traits such as emergence date, cold hardiness and plant height showed a strong clinal pattern along the Pacific coast, suggesting that Garry oaks are locally adapted to their environments (Huebert 2009).

Genetic diversity is maintained in peripheral populations through a combination of immigration, population size, mutation, natural selection, drift, and gene flow (Bialozyt et al. 2005). Typically, genetic patterns of expansion, such as founder effects and genetic drift, lie at the leading edge of a species' range (Keller et al. 2010; Bubac and Spellman 2016). However, many biotic and abiotic factors, including climate change, can greatly influence the degree of gene flow between core and peripheral populations. Climate change is expected to push many species distributions poleward (Chen et al. 2011), including Garry oak habitat (Pellatt et al. 2012; Pellatt and Gedalof 2014). The genetic diversity present in these northern-most populations may provide a basis for adaptive potential (Huebert 2009; Janes and Hamilton 2017), helping GOE persist under increasing environmental stressors and increasing population fragmentation due to urbanization (Pellatt et al. 2012; Pellatt and Gedalof 2014). In addition, long-lived Garry oak ( $>250$ years) may have overlapping generations as a result of vegetative sprouting or transgenerational pollination (Glendenning 1944). Thus, it is important to understand whether variation can be gained or lost over time, and what impact this may have on the persistence and adaptive potential of Garry oak across a broad geographic range.

Here we investigated the genetic structure of Garry oaks using six nuclear microsatellite markers from four populations within the Nanaimo region on Vancouver Island, B.C. The objectives of our study were to answer the following three questions: (1) 
What is the level of genetic diversity within local populations? (2) Does genetic diversity vary between size classes within populations? (3) Are there patterns of genetic differentiation among populations over a relatively small geographic range? Based on the results from previous studies, we did not expect to find a high degree of genetic differentiation among the populations given the relatively close proximity of the sampling sites. Rather, we expected the closest populations would have the lowest differentiation and the highest amount of gene flow. Because of GOE habitat loss and fragmentation in the area around Nanaimo since the arrival of European settlers in the $19^{\text {th }}$ century (Peterson 2003), we predicted either no change, or a reduction, in allelic diversity between older and younger generations. The motivation for studying the genetic structure of Garry oaks is to infer adaptation potential in response to climate change events; information that is critical for assisting land managers and restoration practitioners with conservation planning and ecosystem management activities (Pellatt et al. 2012).

\section{MATERIALS AND METHODS}

\section{Study Area and Sample Collection}

Leaves from 121 randomly-selected Garry oak trees were collected from four populations spanning approximately $56 \mathrm{~km}^{2}$ across Nanaimo, British Columbia, including Neck Point Park (49.2342 N, 123.9643 W), Pipers Lagoon Park (49.2281 N, 123.9501 W), Cable Bay Trail (49.1264 N, 123.8277 W), and Harewood Plains (49.1270 N, 123.9392 W) (Fig. 1). Garry oak communities are generally found in two broadlydefined environmental categories: (1) well-drained, thin rocky soils that are typically 
along shorelines or on rocky bluffs and (2) parkland grass meadows with deep soil and a rich variety of understory vegetation (Roemer 1993; Gedalof et al. 2006). Neck Point Park and Pipers Lagoon are both sea-level peninsulas along the coastline with thin rocky soils and exposure to the marine environment. Cable Bay and Harewood Plains are also shallow soil habitats but are further inland and more sheltered from the coast line.

Fresh leaves were collected off trees in April 2015 and were frozen at $-80^{\circ} \mathrm{C}$ until DNA extraction. Where possible, we ensured a minimum distance of 15-20 m between sampled trees to minimize sampling of highly related individuals (e.g. localized seed dispersal) or clones (e.g. vegetative sprouting). Tree diameter at breast height (dbh) was used to inform general site-specific age classes (Rohner et al. 2013). Dbh is not an accurate indicator of exact tree age (Stewart et al. 2003) as a result of differential abiotic and biotic factors (climate, insects, fire and other disturbances) influencing growth patterns among Garry oak habitats (Thilenius 1964; Smith 2007; Barlow 2017). Hence, each population was split independently into two equal groups with the smallest diameter trees representing a younger subpopulation (hereafter called 'small') and the largest diameter trees representing an older subpopulation (hereafter called 'big'). While this approach limited our ability to directly compare distinct sizes among sites, inferring age classes within populations allowed for a temporal analysis of genetic variation and differentiation (Table 2).

\section{DNA Extraction}

Approximately $25 \mathrm{mg}$ of leaf matter was homogenized using a bead beater (MP Biomedicals FastPrep-24) for 40 seconds at a speed of 4 meters/s. Genomic DNA was 
extracted with DNeasy Plant Mini Kits (Qiagen, Valencia, CA, USA) as per the manufacturer's instructions. DNA was purified and then quantified on a Nanodrop spectrophotometer (ThermoFisher Inc, USA) to normalize the template.

\section{Microsatellite Genotyping}

We genotyped samples at six microsatellite loci previously used in Garry oak (Table S1; Marsico et al. 2009, but see Steinkellner et al. 1997; Aldrich et al. 2002; Aldrich et al. 2003). A polymerase chain reaction (PCR) was performed for each primer pair, using fluorescently-labeled forward primers (see Supplementary Material). The PCR consisted of a total volume of $10 \mu \mathrm{L}$, containing $5 \mu \mathrm{L}$ TopTaq (Qiagen), $1 \mu \mathrm{M}$ of each primer, $1 \mathrm{mM} \mathrm{MgCl}_{2}$ (in addition to TopTaq), and $50 \mu \mathrm{g}$ DNA. The PCR protocol consisted of a 3 -min initial denaturing step at $95^{\circ} \mathrm{C}$ followed by 31 cycles of $30 \mathrm{~s}$ at $95^{\circ} \mathrm{C}$, $15 \mathrm{~s}$ at marker-specific annealing temperatures (Table S1), and $30 \mathrm{~s}$ at $72^{\circ} \mathrm{C}$, with a 10 min final elongation at $72^{\circ} \mathrm{C}$. PCR products were analyzed by the Molecular Biology Service Unit at the University of Alberta on a capillary sequencer (ABI 3730). Digital electropherograms were genotyped by scoring alleles according to fragment length (basepair) using the software GENEIOUS 10.0.9. (Kearse et al. 2012).

\section{Statistical Analysis}

We used a Mann-Whitney $U$ test to verify that our tree diameter categorizations represented distinct size classes within populations. Genotypes were tested for deviations from Hardy-Weinberg equilibrium (HWE) using GENEPOP ON THE WEB (Rousset 2008), and we used MICRO-CHECKER 2.2.3 (van Oosterhout et al. 2004) to determine 
the possibility of null alleles. GenAlEx 6.5 (Peakall and Smouse 2012) was used to determine the average number of alleles $(k)$, observed and expected heterozygosities $\left(H_{O}\right.$ and $H_{E}$ respectively), and inbreeding coefficient $\left(F_{I S}\right)$ for each population. To account for uneven sampling, we also used HP-RARE 1.1 (Kalinowski 2005) to calculate the rarefied allelic richness $\left(\mathrm{A}_{\mathrm{R}}\right)$ and private allelic richness $\left(\mathrm{P}_{\mathrm{A}}\right)$ by standardizing our estimates based on the smallest sample size. Sign tests determined if allelic diversity, rarefied allelic richness or private allelic richness differed between small and big subpopulations within each population separately. A nonparameteric Kruskal-Wallis test determined if allelic diversity, rarefied allelic richness or private allelic richness varied among our four populations and all values are reported as mean \pm standard error. To test for population differentiation, pairwise $F_{S T}$ values were calculated between populations and sizeclassified subpopulations; significance was determined with 9,999 permutations in GenAlEx. To separate how much space and time contribute to differentiation, we conducted a hierarchical analysis of molecular variance (AMOVA) in GenAlEx in which we compared the within-subpopulation, among-subpopulation-but-within-population, and among-population genetic variation.

Bayesian cluster analysis was implemented in STRUCTURE 2.3.4 (Pritchard et al. 2000) to detect distinct genetic groups. We used the following parameters: 100,000 burn-in, 500,000 MCMC iterations, admixture, correlated allele frequencies, and location prior options. The program assessed $K$ 1-8 with 20 iterations of each $K$. We used STRUCTURE HARVESTER (Earl and vonHoldt, 2012) and CLUMPAK (Kopelman et al. 2015) to ensure our analyses converged, and to determine the optimal number of clusters (using the mean $\operatorname{Ln} \operatorname{Pr}(X \mid K)$ ). We repeated the Bayesian analysis within each 
cluster separately to confirm the absence of substructure as per the recommendations in Janes et al. (2017).

\section{RESULTS}

\section{Diameter at Breast Height}

The diameter at breast height measurements from Pipers Lagoon, Neck Point, Cable Bay, and Harewood Plains ranged from 2.5-68.2 cm, 9.1-73.8 cm, 1.2-37.5 cm, and 1.2-41.2 cm respectively (Table 1). Big subpopulations were significantly larger in diameter than small at all populations (Pipers Lagoon $U=399, p<0.0001$, Neck Point $U$ $=110, p<0.0001$, Cable Bay $U=100, p<0.0001$, Harewood Plains $U=400, p<$ 0.0001), confirming that our within-site subpopulation categorization resulted in sizeclasses as planned.

\section{Genetic Diversity}

A genotyping success rate of $92.4 \%$ was achieved across all loci. Significant deviation from HWE $(p<0.05)$ occurred in the Harewood population at locus quru-GA0C19, which MICRO-CHECKER suggested was the result of a possible null allele. However, we chose to retain this locus since it did not deviate from equilibrium in the other three populations. Allelic diversity was low to moderate, ranging from 3.0 to 7.5 alleles per locus with an average of $4.4 \pm 0.3$ across all loci. Markers $\operatorname{ssr} Q p Z A G 9$ and $\operatorname{ssr} Q p Z A G 36$ had the highest allelic diversity $(7.5 \pm 0.9$ and $5.0 \pm 0.4$ alleles per locus, respectively). $H_{O}$ ranged from $0.18-0.70$, with a mean of $0.51 \pm 0.41$ among all loci and populations (Table S1). 
Pipers Lagoon had the highest $H_{O}(0.55 \pm 0.10)$ and the highest levels of allelic diversity (raw $5.0 \pm 0.9$ and rarefied $3.0 \pm 0.6$ ) (Table 1). In contrast, Cable Bay had the lowest $H_{O}(0.46 \pm 0.09)$ and raw allelic diversity $(3.8 \pm 0.5)$ but the second highest allelic diversity after rarefaction $(2.9 \pm 0.6)$. Harewood Plains had moderate raw allelic diversity $(4.7 \pm 0.8)$ and $H_{O}(0.48 \pm 0.09)$, but showed the lowest rarefied allelic diversity $(2.6 \pm$ 0.6). Though Harewood Plains had the highest raw number of private alleles $(n=2$, ssrQpZAG9; $n=1, \operatorname{ssr} Q p Z A G 36 ; n=1, q u r u-G A-0 M 05)$, it actually had the lowest private allelic richness after rarefaction. Overall, there was no significant difference in raw, rarefied or private allelic diversity among the four populations $(H=1.53, p=0.68, H=$ $0.74, p=0.86$ and $H=0.42, p=0.93$ respectively).

\section{Genetic Diversity by Size Class}

$H_{O}$ ranged from $0.37-0.56$, with a mean of $0.48 \pm 0.04$ across all loci and sizeclassified subpopulations. Allelic diversity within size-classified subpopulations ranged from 3.0-4.5 with an average of $3.8 \pm 0.2$ across all loci and subpopulations (Table 1). Both small and big subpopulations from Pipers Lagoon had the highest mean allelic diversity across all loci ( $4.5 \pm 0.1$ and $4.2 \pm 0.7$ respectively), while the big subpopulation from Neck Point and the small subpopulation from Cable Bay exhibited the lowest mean allelic diversity $(3.0 \pm 0.5$ and $3.3 \pm 0.5$ respectively $)$. There were no significant differences in raw (all $p>0.50$ ), rarefied (all $p>0.22$ ) or private allelic diversity (all $\mathrm{p}>$ 0.38 ) between small and big subpopulations within each of the four populations.

\section{Genetic Differentiation Among Populations}


A global $F_{S T}$ of $0.06(p<0.001)$ indicated significant genetic differentiation across all four populations. Pairwise estimates ranged from 0.021 to 0.058 , with the greatest pairwise differences observed for populations compared with Neck Point (Cable Bay $F_{S T}=0.055$; Pipers Lagoon $F_{S T}=0.055$; Harewood Plains $\left.F_{S T}=0.058\right)$ (Table 2). Pipers Lagoon and Neck Point, the most spatially close locations $(<1.5 \mathrm{~km})$, had the second highest degree of genetic differentiation between populations $\left(F_{S T}=0.055\right)$.

After splitting populations into size-classified subpopulations, global $F_{S T}$ increased to $0.09(p<0.001)$. Pairwise $F_{S T}$ values ranged from 0.017 to 0.083 , with the greatest pairwise differences observed between the big subpopulations from Neck Point and Harewood Plains $\left(F_{S T}=0.075\right)$ and between the big subpopulation from Neck Point and the small subpopulation from Cable Bay $\left(F_{S T}=0.083\right)$ (Table 3$)$. None of the four pairwise $F_{S T}$ comparing small vs. big subpopulations within their respective populations showed significant differentiation (all $p>0.257$ ).

The AMOVA revealed that $75 \%(p<0.001)$ of the molecular variance was within individuals, $17 \%(p<0.001)$ among individuals within the same subpopulations, $0 \%(p>$ $0.57)$ among subpopulations within the same populations and $8 \%(p<0.001)$ among populations. Bayesian structure analysis revealed two genetic clusters that separated the populations in the north (Pipers Lagoon and Neck Point) from those in the south (Cable Bay and Harewood Plains) (Fig. 2). Though the big subpopulation from Cable Bay appeared admixed between the two clusters, we found no evidence for further subpopulation structure after conducting hierarchical analyses.

\section{DISCUSSION}


We characterized the genetic diversity of Garry oak populations around the Nanaimo region on Vancouver Island and found moderate to high levels of genetic diversity within populations suggesting that local populations are not genetically depauperate. Even though levels of genetic diversity did not vary among populations, we still found evidence of genetic differentiation among populations, which was unexpected given the relatively small spatial scale of our study and the strong potential for gene flow.

Our global $F_{S T}$ values and AMOVA results were in strong agreement with previous studies that found $F_{S T}$ of 0.049 and $G_{S T}$ of 0.084 for Garry oak populations from Vancouver Island, mainland B.C., Washington and Oregon (Ritland et al. 2005; Marsico et al. 2009). With less than $10 \%$ of the variation explained, the differentiation found in our study was weak, albeit significant, suggesting high overall gene flow among the four populations. This considerable gene flow can likely be attributed to the prevailing wind patterns of south-central Vancouver Island and the consequent impact on pollen dispersal. For example, Fairly and Batchelder (1986) suggest that oak pollen grains can travel as much as $16 \mathrm{~km}$, with their trajectory controlled by prevailing winds. Weather conditions can vary considerably from year to year on Vancouver Island; however, the general pattern of winds over the south coast of B.C. are from the southwest and west (Environment Canada 2014). In the summer months, wind direction changes to a north to northwesterly flow with the development of a Pacific High over the offshore waters (Environment Canada 2014).

Given that Garry oak flowers are wind-pollinated from March to June (Stein 1990), this would suggest that westerly and southwesterly winds would have a large impact on pollen dispersal. This is supported by the particularly high gene flow observed 
between the Harewood Plains and Cable Bay populations in this study. Based on the prevailing winds, Harewood Plains (located most inland and west from the other sampling sites) may be acting as a pollen donor for the more coastal location of Cable Bay. Thus, westerly-wind driven asymmetric gene flow prevents Harewood Plains from receiving new alleles from the other three populations. Garry oak exhibit masting cycles in which flowering and acorn production are increased and synchronized every 2-3 years (Peter and Harrington 2009). Though this synchrony does not include every tree in the population, the overall increase in pollen production and receptive flowers may facilitate additional long distance gene flow (Peter and Harrington 2009). Therefore, our study populations may receive gene flow from more distant populations. However asynchronous pollination in non-mast years as well as continued habitat fragmentation, may inadvertently exacerbate the effects of pollen-mediated gene flow by increasing the geographic distances among patches.

Genetic differentiation was likely weak due to similar levels of allelic diversity among populations. While there was no significant variation in allelic diversity among populations, we did find significant variation in relative allele frequencies among populations. This pattern suggests that differentiation is not the result of a reduction in diversity but instead a lack of gene flow among populations. There is no evidence to suggest that alleles are lost; rather alleles occur at different frequencies in different populations due to genetic drift. In the Bayesian analysis Neck Point and Pipers Lagoon belonged to the same genetic cluster, while Cable Bay and Harewood Plains belonged to another; these results were consistent irrespective of size classes. 
Cable Bay and Harewood Plains occur in the same climatic zone (Zone 8a), while Neck Point and Pipers Lagoon occupy a different climatic zone (Zone 8b) (Natural Resources Canada 2017). These zones represent relatively homogeneous areas with respect to climate conditions and resulting plant survival, thus local populations may adapt to different environmental conditions. The primary difference between Zone $8 \mathrm{a}$ and Zone $8 \mathrm{~b}$ is the extreme minimum temperature, which ranged from $-12.2^{\circ} \mathrm{C}$ to $-9.4^{\circ} \mathrm{C}$ and $9.4^{\circ} \mathrm{C}$ to $-6.7^{\circ} \mathrm{C}$, respectively (Natural Resources Canada 2017). Common garden experiments with Garry oak have determined that seedlings can vary in their emergence date, cold hardiness (Huebert, 2009) and physiological responses to drought; in some cases even when source populations were as little as $\sim 40 \mathrm{~km}$ apart (Merz et al. 2017). These studies may be indicative of local adaptation that contributes to fine-scale genetic structure across microenvironments. Here, we document genetic differentiation between populations less than $2 \mathrm{~km}$ apart (i.e. Pipers Lagoon and Neck Point; Table 2), which is surprising considering these populations are in the same climatic zone; both are exposed to the marine environment and are in clear line of sight of each other.

While we found evidence of genetic differentiation among populations, we did not find any evidence of differentiation between small and big subpopulations. As a result, each small subpopulation appears genetically indistinguishable from its' parent generation, and the populations do not show any signs of increasing or decreasing levels of genetic diversity, nor significant changes in allele frequencies. This lack of temporal structure within each of the four populations suggests either that dbh may not be the best indicator of age or that gene flow and allele transmission have not changed over the length of time captured in our samples. We acknowledge the limitations of using arbitrary 
dbh categories as a proxy for age classes. Diameter at breast height can be a weak predictor of individual tree age (Stewart et al. 2003) given variation in anthropogenic, abiotic and biotic pressures among Garry oak stands (Thilenius 1964; Smith 2007; Barlow 2017). However, dbh provides an indication of average age that has been used successfully in three European oak species (Quercus sp. Rohner et al. 2013), common lime (Tilia cordata), common ash (Fraxinus excelsior) and horsechestnut (Aesculus hippocastanum) (Lukaszkiewicz and Kosmala, 2008). Thus, given that the conditions within the study sites are similar, the relative ages within sites should be approximated by dbh and the comparison of age should be valid.

The lack of temporal structure suggests that there were either no changes in the patterns of gene flow among populations or that transgenerational allele transmission within populations was prevalent during the time captured by our size-classes. Given that most of the genetic variation observed is held within each population, we recognize that this outcome can be obtained even if no gene flow occurs across populations. Hence even if gene flow patterns across the landscape have decreased over time as a result of increased fragmentation, we might not be able to detect these changes as genetic diversity could be maintained independently at each site.

Transgenerational allele transmission within sites is possible through pollination between overlapping generations (shuffling alleles by sexual reproduction) or by vegetative sprouting (perpetuating genotypes by asexual reproduction). Garry oak exhibit both highly-overlapping generations as a result of their longevity ( $>250$ years) and the ability to produce vegetative clones that can further extend their longevity (Glendennning 1944; Taylor and Boss 1975). In addition, the ability of Garry oaks to 
vegetatively reproduce into large stands due to specific environmental conditions (i.e. suckering as a result of steep slopes or stump-sprouting as a result of low-intensity fire regimes) causes the production of large clones (Stewart et al. 2012). The characteristics of clonal growth and highly-overlapping generations provide ample opportunity for transgenerational pollination (Glendenning 1944). Hence, overlapping generations may be responsible for the lack of generation-based differences within small populations even though genetic differentiation was observed among sites that were in close proximity.

In our study, we cannot assume that all big and small populations are the same mean age across sampling locations because each population is exposed to different environmental factors that may impact tree growth for that particular area (i.e. community composition, exposure to climatic elements, etc.) (Thilenius 1964; Smith 2007; Barlow 2017). For instance, Neck Point and Pipers Lagoon populations are situated along coastal shoreline with rocky outcrops. According to Fuchs et al. (2000), many Garry oak seedlings die from desiccation when located in habitats on south-facing slopes with rocky topography. As a result, these environmental variables could challenge establishment rates for oaks located in these areas. Conversely, the Cable Bay and Harewood Plains populations are located inland, in less urbanized and more protected areas that are subject to some conservation initiatives (Parks Canada Agency 2006). The increased altitude for Harewood Plains ( $\sim 93 \mathrm{~m}$ above sea level) may also have a minor impact on precipitation and temperature for the area in comparison to the coastal populations due to an orographic effect.

Our results suggest that these populations are able to maintain genetic diversity over time despite a potential lack of gene flow among populations. Thus, they are 
currently stable from a genetic diversity point of view. The ability to preserve genetic variation may increase the potential for adaptation in response to climate change and help conserve these "at risk" ecosystems. The current decline of GOEs is attributed to a number of factors including fragmentation due to urbanization, competition by invasive species and successional transitions from open to forested areas (Pellatt and Gedalof 2014). The success of Garry oak migration in response to climate change will depend of the ability of this species to persist within a fragmented landscape with varying environmental stressors (Pellatt et al. 2012). Maintaining genetic diversity across generations is important for preserving ecological resilience. However, we should caution that our research did not quantify population size at any point in time, hence we cannot comment on the influence of population size on genetic diversity, though it would seem reasonable to assume that a significant decrease in population size would eventually result in a reduction of genetic diversity.

\section{CONCLUSION}

Our study revealed weak, albeit significant, genetic differentiation among four populations of $Q$. garryana within the Nanaimo region. The strongest genetic differences were between coastal and inland populations, suggesting that habitat fragmentation resulted in decreased gene flow between these groups or that the naturally fragmented habitats at this northern range limit may be an influencing factor. Such fragmentation could increase the probability of local extirpation for Garry oaks, thus conservation efforts should attempt to interconnect isolated habitat patches. Though we detected genetic differentiation among populations, we did not detect any generation-based 
differences within populations. This pattern suggests that there was no net loss of diversity over time in spite of a lack of new gene flow into the populations. This genetic stability may be advantageous for adaptation in response to future selective pressures as the potential for adaptation to climate change depends on genetic variation, dispersal, and establishment rates of Garry oaks (Hertel and Zaspel 1996).

\section{ACKNOWLEDGEMENTS}

We would like to thank Talyn Ridgway, Eric Friesen and Hitomi Kimura for collecting the leaf samples, Susan Sanders, Marlow Pellatt and one anonymous reviewer for feedback on earlier versions of the manuscript, and Corey Davis and Sophie Dang at the University of Alberta who conducted the fragment analyses. This study is the culmination of Erin Catherall's undergraduate thesis. Funding for this project was provided by the Biology Department and the Scholarship, Research, and Creative Activity Office at Vancouver Island University. 


\section{REFERENCES}

Aldrich, P.R., Michler, C.H., Sun, W., and Romero-Severson, J. 2002. Microsatellite markers for northern red oak (Fagaceae: Quercus rubra). Mol. Ecol. Notes, 2: 472474.

Aldrich, P.R., Jagtap, M., Michler, C.H., and Romero-Severson, J. 2003. Amplification of North American red oak microsatellite markers in European white oaks and Chinese chestnut. Silvae Genetica, 52: 176-179.

Barlow, C.M. 2017. Garry oak ecosystem stand history in southwest British Columbia: Implications for restoration, management and population recovery. MRM Thesis, Simon Fraser University, Vancouver, BC, 59p.

Bialozyt, R., Ziegenhagen, B., and Petit, R.J. 2005. Contrasting effects of long distance seed dispersal on genetic diversity during range expansion. J. Evol. Biol. 19: 12-20.

Brown, K.J., and Hebda, R.J. 2002. Origin, development, and dynamics of coastal temperate conifer rainforests of southern Vancouver Island, Canada. Can. J. For. Res. 32: 353-372.

Bubac, C.M., and Spellman, G.M. 2016. How connectivity shapes genetic structure during range expansion: Insights from the Virginia's Warbler. The Auk, 133: 213230.

Burke, L.A., Myers, J.A., and Belote, R.T. 2015. Wildfire disturbance and productivity as drivers of plant species diversity across spatial scales. Ecosphere, 6: 202-214.

Chen, I.C., Hill, J.K., Ohlemuller, R., Roy, D.B., and Thomas, C.D. 2011, Rapid Range 
Shifts of Species Associated with High Levels of Climate Warming. Science, 333: 1024-1026.

Darling, L. M. 2000. Proceedings of a Conference on the Biology and Management of Species and Habitats at Risk, Kamloops, BC, 15 - 19 Feburary 1999. Ministry of Environment, Lands and Parks, Victoria, BC and University College of the Cariboo, Kamloops, BC, 490p.

Davis, M. B., and Shaw, R.G. 2001. Range shifts and adaptive responses to Quaternary climate change. Science, 292: 673-679.

Dunwiddie, P.W., Bakker, J.D., Almaguer-Bay, M., and Sprenger, C.B. 2011. Environmental history of a Garry oak/Douglas-fir woodland on Waldron Island, Washington. Northwest Science, 85: 130-140.

Earl, D.A., and vonHoldt, B.M. 2012. STRUCTURE HARVESTER: a website and program for visualizing STRUCTURE output and implementing the Evanno method. Conserv. Genet. Resour. 4: 359-361.

Environment Canada and U.S. Environmental Protection Agency. 2014. Georgia Basin Puget Sound Airshed Characterization Report, 2014. Edited by R. Vingarzan, R. So, and R. Kotchenruther. Environment Canada, Pacific and Yukon Region, Vancouver (BC). U.S. Environmental Protection Agency, Region 10, Seattle (WA). ISBN 978-1-100 22695-8. Cat. No.: En84-3/2013E-PDF. EPA 910-R-14-002 
Erickson, W.R. 1996. Classification and interpretation of Garry oak (Quercus garryana) plant communities and ecosystems in southwestern British Columbia. MSc Thesis, University of Victoria, Victoria, BC, 542p.

Fairley, D., and Batchelder, G.L. 1986. A study of oak-pollen production and phenology in northern California: prediction of annual variation in pollen counts based on geographic and meterologic factors. J. Allergy Clin. Immunol. 78(2): 300-307.

Fuchs, M.A. 2001. Towards a recovery strategy for Garry oak and associated ecosystems. Ecological assessment and literature review. Pacific and Yukon Region, Canadian Wildlife Service, Environment Canada. Technical Report GBEI/EI-00-030.

Fuchs, M.A., Krannitz, P.G., and Harestad, A.S. 2000. Factors affecting emergence and first-year survival of seedlings of Garry oaks (Quercus garryana) in British Columbia, Canada. For. Ecol. Manage. 137: 209-219.

Gedalof, Z., Pellatt, M., and Smith, D.J. 2006. From prairie to forest: Three centuries of environmental change at Rocky Point, Vancouver Island, British Columbia. Northwest Science, 80: 34-46.

Glendenning, R. 1944. The garry oak in British Columbia: an interesting example of discontinuous distribution. Can. Field-Nat. 58: 61-65.

Hertel, H., and Zaspel, I. 1996. Investigations on vitality and genetic structure in oak stands. Ann. For. Sci. 53: 761-773. 
Huebert, C.A. 2009. The ecological and conservation genetics of Garry oak (Quercus garryana Dougl. ex Hook). MSc Thesis, University of British Columbia, Vancouver, BC, 62p.

Janes, J.K., Miller, J.M., Dupuis, J.R., Malenfant, R.M., Gorrell, J.C., Cullingham, C.I., and Andrew, R.L. 2017. The K=2 conundrum. Mol. Ecol. 26(14): 3594-3602. doi:10.1111/mec.14187

Janes, J.K., and Hamilton, J.A. 2017. Mixing it up: the role of hybridization in forest management and conservation under climate change. Forests, 8(7): 237-253. doi:10.3390/f8070237

Kalinowski, S.T. 2005. HP-Rare: a computer program for performing rarefaction on measures of allelic diversity. Mol. Ecol. Notes, 5: 187-189.

Kearse, M., Moir, R., Wilson, A., Stones-Havas, S., Cheung, M., Sturrock, S., Buxton, S., Cooper, A., Markowitz, S., Duran, C., Thierer, T., Ashton, B., Mentjies, P., and Drummond, A. 2012. Geneious Basic: an integrated and extendable desktop software platform for the organization and analysis of sequence data. Bioinformatics, 28(12): 1647-1649.

Kopelman, N.M., Mayzel, J., Jakobsson, M., Rosenberg, N.A., and Mayrose, I. 2015. CLUMPAK: a program for identifying clustering modes and packaging population structure inferences across K. Mol. Ecol. Resour. 15(5): 1179-1191. 
Lukaszkiewicz, J., Kosmala, M. 2008. Determining the age of streetside trees with a diameter at breast height-based multifactorial model. Arboriculture \& Urban Forestry, 34: 137-143.

MacDougall, A., Beckwith, B.R., and Maslovat, C.Y. 2004. Defining conservation strategies with historical perspectives: a case study from a degraded oak grassland ecosystem. Conserv. Biol. 18(2): 455-465.

Marsico, T.D., Hellmann, J.J., and Romero-Serverson, J. 2009. Patterns of seed dispersal and pollen flow in Quercus garryana following post-glacial climatic changes. J. Biogeogr. 36(5): 929-941.

McCoy, M.M. 2006. High resolution fire and vegetation history of Garry oak ecosystems in British Columbia. MSc Thesis, Simon Fraser University, Vancouver, BC, 88p.

Merz, M.A., Donahue, R.A., and Poulson, M.E. 2017. Physiological response of Garry oak (Quercus garryana) seedlings to drought. Northwest Science, 91: 140-159.

Natural Resources Canada. 2017. Plant Hardiness Zone Maps, Plant Hardiness of Canada. http://www.planthardiness.gc.ca/

Parks Canada Agency. 2006. Recovery Strategy for Multi-species at Risk in Vernal Pools and Other Ephemeral Wet Areas in Garry Oak and Associated Ecosystems in Canada. In Species at Risk Act Recovery Strategy Series. Ottawa: Parks Canada Agency. 73p. 
Peakall, R., and Smouse, P.E. 2012. GenAlEx 6.5: genetic analysis in Excel. Population genetic software for teaching and research-an update. Bioinformatics, 28: 25372539.

Pellatt, M.G., Hebda, R.J. and Mathewes, R.W. 2001. High resolution Holocene vegetation history and climate from Hole 1034B, ODP Leg 169S, Saanich Inlet, Canada. Marine Geology, 174: 211-226.

Pellatt, M.G., Goring, S.J., Bodtker, K.M., and Cannon, A.J. 2012. Using a down-scaled bioclimate envelope model to determine long-term temporal connectivity of Garry oak (Quercus garryana) habitat in Western North America: Implications for protected area planning. Environ. Manage. 49: 802-815.

Pellatt, M.G., and Gedalof, Z. 2014. Environmental change in Garry oak (Quercus garryana) ecosystems: The evolution of an eco-cultural landscape. Biodivers. Conserv. 23(8): 2053-2067.

Peter, D., and Harrington, C. 2009. Synchronicity and Geographic Variation in Oregon White Oak Acorn Production in the Pacific Northwest. Northwest Science, 83: 117130.

Peterson, J. 2003. Hub City: Nanaimo, 1886-1920. Surrey, BC: Heritage House Publishing Company. ISBN 9781894384667.

Pritchard, J.K., Stephens, M., and Donnelly, P. 2000. Inference of population structure using multilocus genotype data. Genetics, 155: 945-959. 
Roemer, H. 1993. Vegetation and ecology of Garry oak woodlands. In Garry Oakmeadow Colloquium proceedings. Edited by R. J. Hebda and F. Aitkens. Garry Oak Meadow Preservation Society, Victoria, BC. pp 19-24.

Rohner, B., Bugmann, H., and Bigler, C. 2013. Estimating the age-diameter relationship of oak species in Switzerland using nonlinear mixed-effects models. Eur. J. For. Res. 132: 751-764.

Rousset, F. 2008. Genepop'007: a complete reimplementation of the Genepop software for Windows and Linux. Mol. Ecol. Resour. 8: 103-106.

Ritland, K., Meagher, L.D., Edwards, D.G.W., and Y.A. El-Kassaby. 2005. Isozyme variation and the conservation genetics of Garry oak. Can. J. Bot. 83(11): 14781487.

Savolainen, O., Pyhajarvi, T., and T. Knurr. 2007. Gene flow and local adaptation in trees. Annu. Rev. Ecol. Evol. Syst. 38: 595-619.

Smith, S. 2007 Garry oak savannah dynamics in the Gulf Islands National Park Reserve: pattern and process of forest encroachment. MSc Thesis, University of Guelph, Guelph, ON, 167p.

Stewart, B.J., Neily, P.D, Quigley, E.J., Duke, A.P., Benjamin, L.K. 2003. Selected Nova Scotia old-growth forests: Age, ecology, structure, scoring. For. Chron. 79(3), 632644. 
Stewart, J.M., Marsico, T.D., Burge, D., Hellmann, J.J. 2012. Largest Known Quercus garryana Douglas ex Hook Clone Discovered on a Steep Slope at the Boundary of Larrabee State Park, Washington, USA. International Oak Journal, 23, 68-75.

Stein, W.I. 1990. Quercus garryana Dougl. ex Hook. Silviculture of North America: Agricultural Handbook 654 (2) Department of Agriculture, Timber Management Research, Washington, DC. p. 650-660.

Steinkellner, H., Lexer, C., Turetschek, E., and Glössl, J. 1997. Conservation of (GA)n microsatellite loci between Quercus species. Mol. Ecol. 12: 1189-1194.

Taylor, R.J., and Boss, T.R. 1975. Biosystematics of Quercus garryana in relation to its distribution in the State of Washington. Northwest Science 49: 49-57.

Thilenius, J.F. 1964. Synecology of the white-oak (Quercus garryana Douglas) woodlands of the Willamette Valley, Oregon. PhD Thesis, Oregon State University, Corvallis, OR. 151p.

van Oosterhout, C., Hutchinson, W.F., Willis, D.P.M., and Shipley, P. 2004. MicroChecker: software for identifying and correcting genotyping errors in microsatellite data. Mol. Ecol. Notes, 4: 535-538.

Ward, P., Radcliffe, G., Kirky, J., Illingtonworth, J., and Cadrin, C. 1998. Sensitive ecosystems inventory: East Vancouver Island and Gulf Islands, 1993-1997. Vol. 1. Methodology, ecological descriptions and results. Pacific and Yukon Region, Canadian Wildlife Service, B.C. Technical Report Series No. 320. 
Table 1: Summary statistics across four populations (subdivided into size classes) including sample size (n), average, minimum and maximum tree diameter at breast height, allelic diversity $(k)$, rarefied allelic richness $\left(\mathrm{A}_{\mathrm{R}}\right)$, private allelic richness $\left(\mathrm{P}_{\mathrm{A}}\right)$, observed heterozygosity $\left(H_{O}\right)$, expected heterozygosity $\left(H_{E}\right)$, and inbreeding coefficient $\left(F_{I S}\right)$. Variance estimates are standard errors.

\begin{tabular}{|c|c|c|c|c|c|c|c|c|c|c|}
\hline \multirow{2}{*}{$\begin{array}{l}\text { Population } \\
\text { and } \\
\text { size-class }\end{array}$} & \multirow[b]{2}{*}{$\mathrm{n}$} & \multicolumn{3}{|c|}{ Tree diameter $(\mathrm{cm})$} & \multicolumn{6}{|c|}{ Genetic diversity } \\
\hline & & Mean & Min. & Max. & $k$ & $\mathrm{~A}_{\mathrm{R}}$ & $\mathrm{P}_{\mathrm{A}}$ & $H_{O}$ & $H_{E}$ & $F_{I S}$ \\
\hline Pipers & 40 & $25.4 \pm 2.9$ & 2.5 & 68.2 & $5.0 \pm 0.9$ & $3.0 \pm 0.4$ & $0.4 \pm 0.2$ & $0.51 \pm 0.10$ & $0.55 \pm 0.10$ & $0.09 \pm 0.04$ \\
\hline small & 21 & $11.0 \pm 1.3$ & 2.5 & 18.8 & $4.5 \pm 0.8$ & $2.3 \pm 0.3$ & $0.2 \pm 0.1$ & $0.49 \pm 0.11$ & $0.57 \pm 0.09$ & $0.19 \pm 0.09$ \\
\hline big & 19 & $41.4 \pm 3.1$ & 26.9 & 68.2 & & $2.2 \pm 0.3$ & $0.2 \pm 0.1$ & $0.52 \pm 0.09$ & $0.51 \pm 0.10$ & $-0.05 \pm 0.05$ \\
\hline Neck & 21 & $35.1 \pm 4.5$ & 9.1 & 73.8 & $4.0 \pm 0.9$ & $2.7 \pm 0.4$ & $0.4 \pm 0.2$ & $0.47 \pm 0.09$ & $0.48 \pm 0.07$ & $0.01 \pm 0.10$ \\
\hline small & 11 & $19.2 \pm 1.9$ & 9.1 & 28.0 & $3.5 \pm 0.9$ & $2.0 \pm 0.2$ & $0.2 \pm 0.1$ & $0.40 \pm 0.12$ & $0.46 \pm 0.08$ & $0.12 \pm 0.18$ \\
\hline big & 10 & $52.5 \pm 4.9$ & 35.2 & 73.8 & $3.0 \pm 0.5$ & $2.0 \pm 0.2$ & $0.2 \pm 0.1$ & $0.54 \pm 0.09$ & $0.45 \pm 0.08$ & $-0.21 \pm 0.04$ \\
\hline Harewood & 40 & $15.6 \pm 1.6$ & 1.2 & 37.5 & $4.7 \pm 0.8$ & $2.6 \pm 0.4$ & $0.3 \pm 0.1$ & $0.49 \pm 0.10$ & $0.48 \pm 0.09$ & $0.03 \pm 0.10$ \\
\hline small & 20 & $6.7 \pm 0.7$ & 1.2 & 10.8 & $4.0 \pm 0.5$ & $2.1 \pm 0.2$ & $0.1 \pm 0.0$ & $0.51 \pm 0.11$ & $0.49 \pm 0.09$ & $0.03 \pm 0.14$ \\
\hline big & 20 & $24.5 \pm 1.3$ & 17 & 37.5 & $3.8 \pm 0.6$ & $2.0 \pm 0.2$ & $0.1 \pm 0.1$ & $0.47 \pm 0.09$ & $0.46 \pm 0.10$ & $-0.04 \pm 0.04$ \\
\hline Cable & 20 & $18.8 \pm 3.3$ & 1.2 & 41.2 & $3.8 \pm 0.5$ & $2.9 \pm 0.3$ & $0.5 \pm 0.2$ & $0.46 \pm 0.09$ & $0.53 \pm 0.09$ & $0.17 \pm 0.06$ \\
\hline small & 10 & $5.2 \pm 1.4$ & 1.2 & 13.3 & $3.3 \pm 0.5$ & $2.1 \pm 0.2$ & $0.2 \pm 0.1$ & $0.37 \pm 0.09$ & $0.49 \pm 0.09$ & $0.24 \pm 0.13$ \\
\hline big & 10 & $32.4 \pm 1.5$ & 25.4 & 41.2 & $3.7 \pm 0.6$ & $2.3 \pm 0.2$ & $0.3 \pm 0.1$ & $0.56 \pm 0.11$ & $0.55 \pm 0.09$ & $0.03 \pm 0.13$ \\
\hline
\end{tabular}


Table 2: Pairwise $F_{S T}$ values for four populations are displayed below the diagonal and geographic distances (km) are above the diagonal.

\begin{tabular}{c|cccc}
\hline \multirow{2}{*}{ Neck } & Neck & Cable & Harewood & Pipers \\
\cline { 2 - 5 } Cable & - & 15.8 & 12.0 & 1.5 \\
Harewood & 0.055 & - & 8.1 & 14.5 \\
Pipers & 0.058 & 0.021 & - & 11.2 \\
\hline
\end{tabular}

Note: All $F_{S T}$ estimates were significantly greater than zero $(p<0.05)$ after 9,999 permutations. 
Table 3: Pairwise $\mathrm{F}_{\mathrm{ST}}$ values for four populations split into size-classified subpopulations are displayed below the diagonal. Values above the diagonal are probabilities of $F_{S T}>0$ based on 9,999 permutations.

\begin{tabular}{c|cccccccc}
\hline \multicolumn{1}{c}{} & $\begin{array}{c}\text { Cable } \\
\text { big }\end{array}$ & $\begin{array}{c}\text { Cable } \\
\text { small }\end{array}$ & $\begin{array}{c}\text { Harewood } \\
\text { big }\end{array}$ & $\begin{array}{c}\text { Harewood } \\
\text { small }\end{array}$ & $\begin{array}{c}\text { Neck } \\
\text { big }\end{array}$ & $\begin{array}{c}\text { Neck } \\
\text { small }\end{array}$ & $\begin{array}{c}\text { Pipers } \\
\text { big }\end{array}$ & $\begin{array}{c}\text { Pipers } \\
\text { small }\end{array}$ \\
\cline { 2 - 8 } Cable big & - & 0.695 & 0.026 & 0.060 & 0.053 & 0.438 & 0.049 & 0.092 \\
Cable small & 0.022 & - & 0.203 & 0.324 & 0.008 & 0.171 & 0.107 & 0.054 \\
Harewood big & 0.044 & 0.029 & - & 0.729 & 0.001 & 0.016 & 0.004 & 0.008 \\
Harewood small & 0.040 & 0.025 & 0.009 & - & 0.001 & 0.024 & 0.001 & 0.003 \\
Neck big & 0.048 & 0.083 & 0.075 & 0.067 & - & 0.257 & 0.000 & 0.003 \\
Neck small & 0.027 & 0.041 & 0.045 & 0.043 & 0.030 & - & 0.145 & 0.057 \\
Pipers big & 0.036 & 0.034 & 0.037 & 0.044 & 0.072 & 0.027 & - & 0.296 \\
Pipers small & 0.039 & 0.045 & 0.038 & 0.042 & 0.061 & 0.039 & 0.017 & - \\
\hline
\end{tabular}




\section{Figure captions}

Figure 1: Map of four Garry oak populations in the Nanaimo region on Vancouver Island. (Base map Copyright (C) 2018 Esri and its licensors. All rights reserved.)

Figure 2. Bar plot from STRUCTURE showing two genetic clusters after genotyping samples from four populations at six nuclear microsatellites. Each population was split into big and small size-class subpopulations based on tree diameter at breast height. 


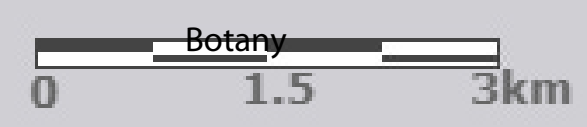

- Neck Point Park

- Piper's Lagoon Park

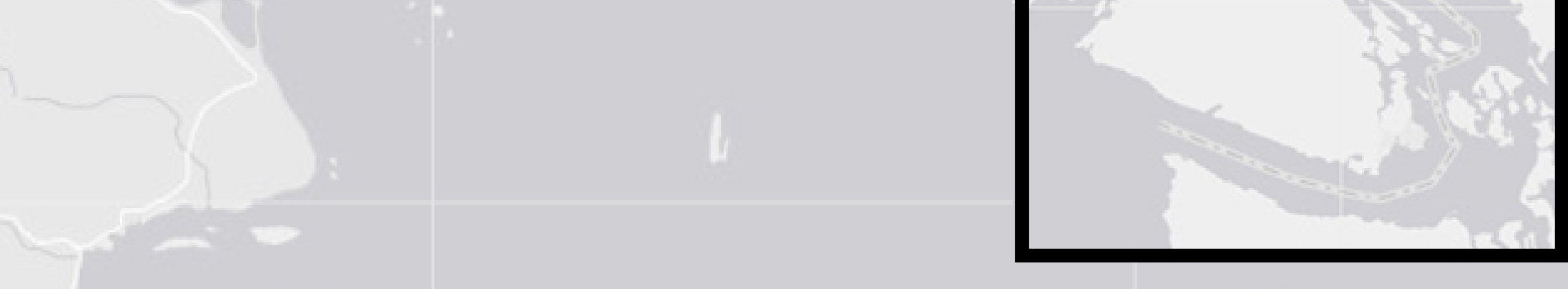

\section{Departure}

Bay

\section{Nanaimo}

Gabriola

- Harewood Plains

Starks

https://mc06.manuscriptcentral.com/botany-pubs 


\section{Page 33 of 33}

Botany

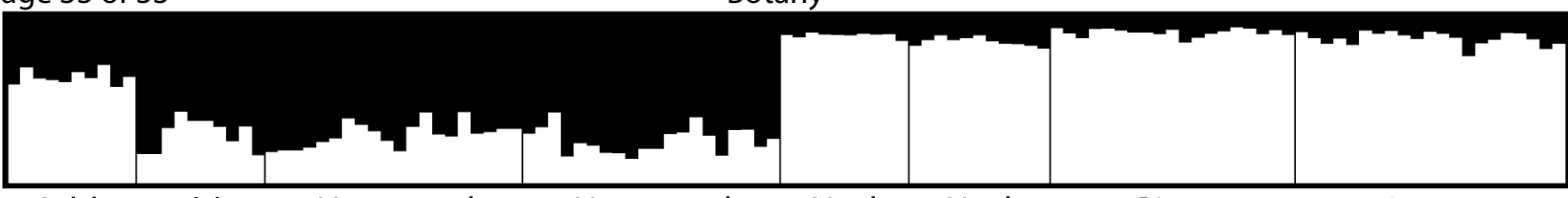

Cable Cable

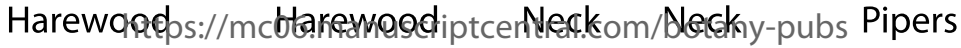

Pipers

big small

big

small

big small

big

small 